\title{
EFFECT OF EXPECTED CLIMATE CHANGES ON THE WATER NEEDS OF FOREST NURSERY IN THE REGION OF CENTRAL POLAND
}

Stanisław ROLBIECKI, Department of Land Melioration and Agrometeorology; University of Science and Technology in Bydgoszcz; Bernardyńska 6, 85-029 Bydgoszcz, Poland; e-mail: rolbs@utp.edu.pl

Mateusz KOKOSZEWSKI, Department of Land Melioration and Agrometeorology; University of Science and Technology in Bydgoszcz; Bernardyńska 6, 85-029 Bydgoszcz, Poland; e-mail: mateuszkokoszewski@wp.pl

Vilda GRIBAUSKIENE, Institute of Water Resources Management. Aleksandras Stulginskis University in Kaunas, Studentu g. 10. Lithuania e-mail: vilda.grybauskiene@ asu.lt

Roman ROLBIECKI, Department of Land Melioration and Agrometeorology; University of Science and Technology in Bydgoszcz; Bernardyńska 6, 85-029 Bydgoszcz, Poland; e-mail: rolbr@utp.edu.pl (corresponding author)

Barbara JAGOSZ, Institute of Plant Biology and Biotechnology; University of Agriculture in Krakow; 29 Listopada 54, 31-425 Krakow, Poland; e-mail: bjagosz@ogr.ar.krakow.pl

Wieslaw PTACH, Department of Civil Engineering; Warsaw University of Life Sciences; Nowoursynowska 159, 02-776 Warszawa, Poland; e-mail: wieslaw_ptach@sggw.pl

Ariel LANGOWSKI, Department of Land Melioration and Agrometeorology; University of Science and Technology in Bydgoszcz; Bernardyńska 6, 85-029 Bydgoszcz, Poland; e-mail: ariellangowski@ gmail.com

The aim of the study was to estimate the water needs of forest nursery in 2021-2050 in the region of Bydgoszcz (central Poland) basing on the predicted changes of air temperature. The forecast of average monthly air temperature for the Bydgoszcz region in 2011-2050, according to the expected climate change in Poland (SRES: A1B), was applied. The water requirements of forest nursery were determined basing on the daily water consumption for plant transpiration and field evaporation. The water needs were estimated for two types of the soil: sandy and clay, in the period from April to September for each year from 2021 to 2050 . The reference period was 30 years from 1981 to 2010. According to the calculations, during 2021-2050 in the Bydgoszcz region, the forecasted water needs of forest nurseries will increase by $12-15 \%$. In relation to the reference period and according to the expected climate changes, the water needs of forest nurseries in 2021-2050 will raise during the growing period from 427 to $489 \mathrm{~mm}$ on clay and from 498 to $560 \mathrm{~mm}$ on sandy soil. The greatest water needs, occurred in July, were 110 and $137 \mathrm{~mm}$ on the clay and sandy soil, respectively. Correlation and regression analysis showed that the water needs of forest nurseries in 2021-2050 will significantly increase in April by 3.3 and 3.8 $\mathrm{mm} \cdot \mathrm{decade}^{-1}$, and in August by 5.4 and by $6.0 \mathrm{~mm} \cdot \mathrm{decade}^{-1}$ on the clay and sandy soils, respectively.

Keywords: forest nursery, water requirements, climate change, Bydgoszcz region, central Poland

\section{INTRODUCTION}

The expected climate changes predict a significant increase in air temperature, but only a slight raise in annual precipitation (Schmidt et al., 2006). Moreover, the increase of precipitation is expected mainly during the winter. The simulations carried out for central Poland indicate a lack or non-significant for the plant production increase of rainfall in the period from April to August (Kuchar and Iwański, 2011, 2013). Consequently, the amount of water available to the plants will decrease. The region of Bydgoszcz, located in the northern part of central Poland, is particularly vulnerable to the lack of precipitation during growing period (Kuchar and Iwański, 2011, 2013; Kuchar et al., 2015, 2017; Żarski et al., 2013). The analysis of expected climate changes in Poland indicated the problem of precipitation deficit that in the case of poor retention potential of the majority Polish soils can negatively influenced the growth and development of plants (Łabędzki, 2009; Orlińska-Woźniak et al., 2013). Therefore, during the next 30-50, probably will be necessary to irrigate the plants and its level will have to be adapted to the type of soil and to the region of country.

The expected climate changes are especially adverse for nursery production, whose effects are depends mainly on the optimal water-soil conditions (Pierzgalski et al., 2002; Rzekanowski and Pierzgalski, 2006; Rolbiecki et al., 2010; Grybauskiene et al., 2018). In Poland, the "State Forests" organization produce plants in about 1400 forest nurseries with total area of nearly 3500 hectares (Rzekanowski and Pierzgalski, 2006). The water deficiencies in Poland are mainly due to low and/or irregular rainfall during the growing period (Żarski et al., 2013). The water deficit and the expected climate

Copyright (C) 2017 The Authors. Published by Aleksandras Stulginskis University. This is an open-access article distributed under the terms of the Creative Commons Attribution License (CC-BY 4.0), which permits unrestricted use, distribution, and reproduction in any medium, provided the original author and source are credited. 
changes can significantly reduce the yield and quality of nursery production, especially in the case of large nurseries located on the sandy soils (Pierzgalski et al., 2002).

The appropriate moisture content of soil is essential for the germination of seeds and seedling development. For that reason irrigation of forest nurseries is one of the most important melioration treatments, so that nearly $90 \%$ of the nurseries are equipped with the watering facilities equipment (Rzekanowski and Pierzgalski, 2006). Ensuring optimum water conditions for soil in nursery production is one of the most important objectives of water management in forest (Pierzgalski, 2009). Therefore, the forest breeding program recommended the creation of nurseries with an area of over 3 hectares and with the ability to install the irrigation system (Pierzgalski et al., 2002).

The aim of the study was to estimate the water needs of forest nurseries during the years 2021-2050 in the region of Bydgoszcz (central Poland) on the sandy and clay soils. The water requirements were calculated on the basis of predicted changes in air temperature.

\section{MATERIAL AND METHODS}

In the study, the forecasts of average monthly air temperature in the region of Bydgoszcz for the years 20112050, according to the expected climate change in Poland SRES: A1B (Bąk i Łabędzki 2014), was applied. The water needs of the forest nurseries were determined basing on daily water consumption for the plant transpiration and field evaporation of the controlled layer of soil (Pierzgalski et al., 2002). The studied nurseries were located on two types of soil, sandy and clay soil, which differed in terms of water potential. The water requirements were estimated for the period from April to September for each year from 2021 to 2050. The reference period was 30 years from 1981 to 2010.

The results of the study were statistically analyzed using computer package (Excel spreadsheet). The mean, median, maximum and minimum values, as well the standard deviation and variability coefficient, were estimated. Also, the calculation of possible trends in the water needs changes of forest nurseries using linear regression analysis with evaluation of correlation and determination coefficients was performed. The significance of correlation coefficient, for $\mathrm{n}$ $=30$, was determined at the level of $\alpha=0.1$. The value of the correlation coefficient was significant for $r \alpha \geq 0.264$.

\section{RESULTS AND DISCUSSION}

The total water needs of the studied forest nurseries during the growing period (from April to September) were more varied in the years 2021-2050 (the variability coefficient ranged from 7.2 to $7.4 \%$ ) than in the reference period 1981-2010 (the variability coefficient was 4.7\%) (Table 1). In the years 2021-2050, the predicted variability of water requirements in April, May, June and August was higher than during the reference period. The variation of water needs in July and September was similar in both compared thirty-year periods.

Table 1. Water needs of forest nurseries (mm) in the years 1981-2010 and 2021-2050

\begin{tabular}{|c|c|c|c|c|c|c|c|c|}
\hline \multicolumn{2}{|l|}{ Specification } & April & May & June & July & August & September & April-September \\
\hline \multicolumn{9}{|c|}{ Period from 1981 to 2010} \\
\hline \multirow{2}{*}{ Mean } & $\mathrm{C}$ & 41.9 & 68.9 & 78.3 & 96.4 & 86.2 & 55.0 & 426.7 \\
\hline & $\mathrm{S}$ & 50.8 & 82.4 & 93.6 & 120.5 & 95.9 & 55.0 & 498.1 \\
\hline \multirow{2}{*}{ Minimum } & $\mathrm{C}$ & 25.2 & 56.7 & 70.5 & 83.1 & 73.3 & 28.4 & 401.1 \\
\hline & $\mathrm{S}$ & 31.2 & 67.9 & 85.5 & 103.7 & 81.2 & 28.4 & 465.8 \\
\hline \multirow{2}{*}{ Maximum } & $\mathrm{C}$ & 52.2 & 76.6 & 92.7 & 126.3 & 113.1 & 64.5 & 492.7 \\
\hline & $\mathrm{S}$ & 61.5 & 92.1 & 111.3 & 157.2 & 125.6 & 64.5 & 574.7 \\
\hline \multirow{2}{*}{ Median } & $\mathrm{C}$ & 42.6 & 69.7 & 78.6 & 93.3 & 83.7 & 56.2 & 424.8 \\
\hline & S & 51.6 & 83.7 & 93.9 & 116.7 & 93.0 & 56.2 & 494.8 \\
\hline \multirow{2}{*}{ SD } & $\mathrm{C}$ & 5.2 & 2.9 & 4.5 & 10.7 & 7.7 & 7.2 & 20.1 \\
\hline & $\mathrm{S}$ & 5.8 & 3.6 & 5.0 & 13.4 & 8.5 & 7.2 & 23.6 \\
\hline \multirow{2}{*}{$\mathrm{VC}(\%)$} & $\mathrm{C}$ & 12.3 & 4.2 & 5.7 & 11.1 & 8.9 & 13.1 & 4.7 \\
\hline & $\mathrm{S}$ & 11.5 & 4.4 & 5.4 & 11.1 & 8.9 & 13.1 & 4.7 \\
\hline \multicolumn{9}{|c|}{ Period from 2021 to 2050} \\
\hline \multirow{2}{*}{ Mean } & $\mathrm{C}$ & 41.0 & 68.5 & 83.8 & 109.7 & 111.4 & 74.6 & 489.3 \\
\hline & $\mathrm{S}$ & 49.7 & 80.9 & 99.7 & 137.2 & 124.0 & 68.8 & 560.3 \\
\hline \multirow{2}{*}{ Minimum } & $\mathrm{C}$ & 18.8 & 54.4 & 69.0 & 89.0 & 83.7 & 60.0 & 418.7 \\
\hline & $\mathrm{S}$ & 24.2 & 65.2 & 83.2 & 110.7 & 93.0 & 56.2 & 460.6 \\
\hline \multirow{2}{*}{ Maximum } & $\mathrm{C}$ & 60.9 & 88.0 & 105.0 & 132.1 & 141.7 & 91.3 & 564.6 \\
\hline & $\mathrm{S}$ & 74.1 & 106.6 & 125.2 & 165.5 & 157.2 & 91.3 & 651.8 \\
\hline \multirow{2}{*}{ Median } & $\mathrm{C}$ & 44.4 & 69.7 & 82.3 & 109.3 & 109.4 & 72.4 & 493.2 \\
\hline & $\mathrm{S}$ & 53.4 & 82.5 & 97.5 & 136.7 & 124.6 & 66.0 & 563.0 \\
\hline \multirow{2}{*}{ SD } & $\mathrm{C}$ & 9.1 & 6.8 & 8.9 & 12.1 & 14.4 & 9.8 & 36.5 \\
\hline & $\mathrm{S}$ & 10.6 & 7.2 & 10.7 & 15.0 & 15.8 & 8.9 & 40.2 \\
\hline \multirow{2}{*}{$\mathrm{VC}(\%)$} & $\mathrm{C}$ & 22.2 & 9.9 & 10.6 & 11.0 & 12.9 & 13.2 & 7.4 \\
\hline & $\mathrm{S}$ & 21.3 & 8.9 & 10.7 & 10.9 & 12.7 & 12.9 & 7.2 \\
\hline
\end{tabular}

SD - standard deviation; VC - variability coefficient; C - clay soils; $\mathrm{S}$ - sandy soils 


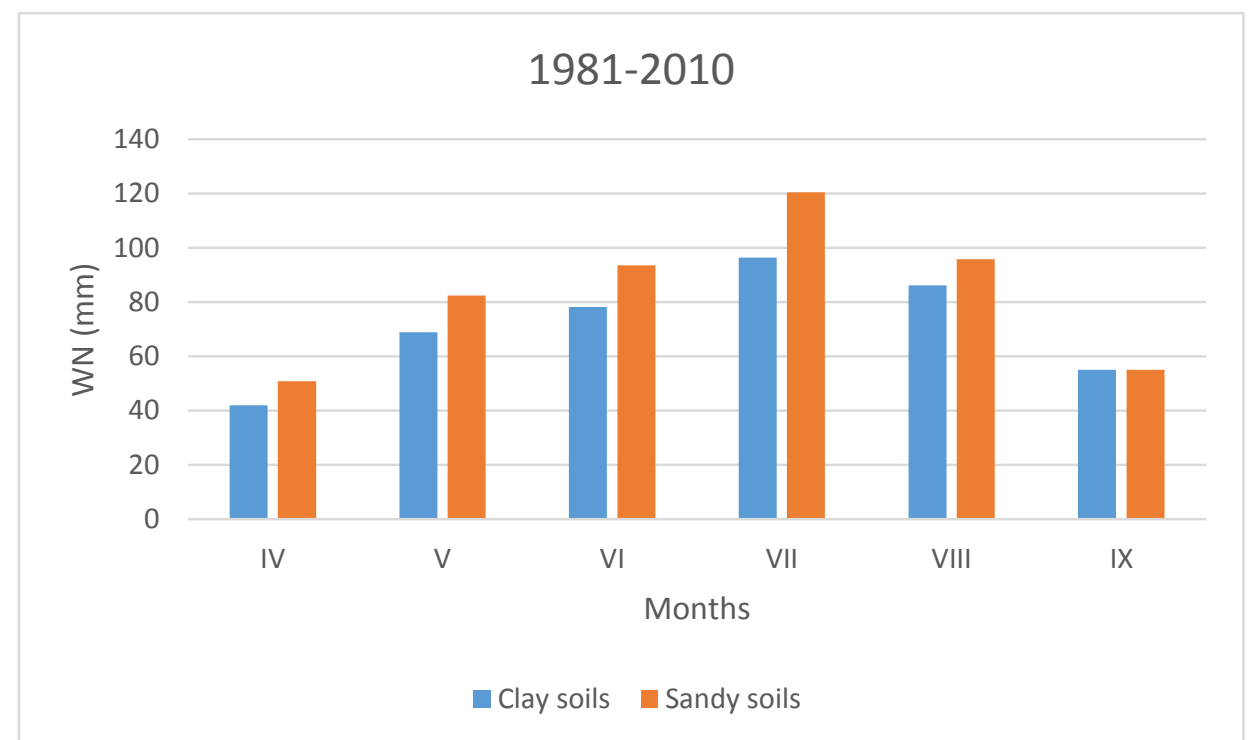

Figure 1. Water needs (WN) of forest nurseries in the particular months of growing period 1981-2010

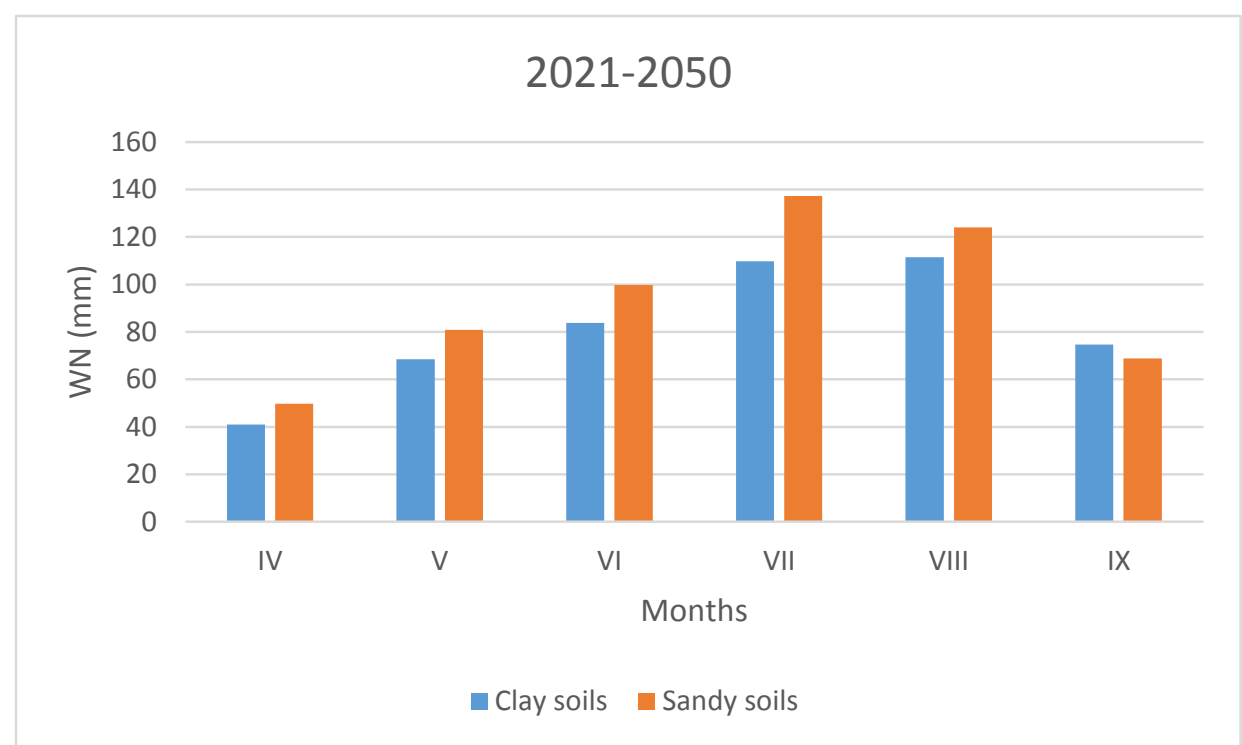

Figure 2. Water needs (WN) of forest nurseries in the particular months of growing period 2021-2050

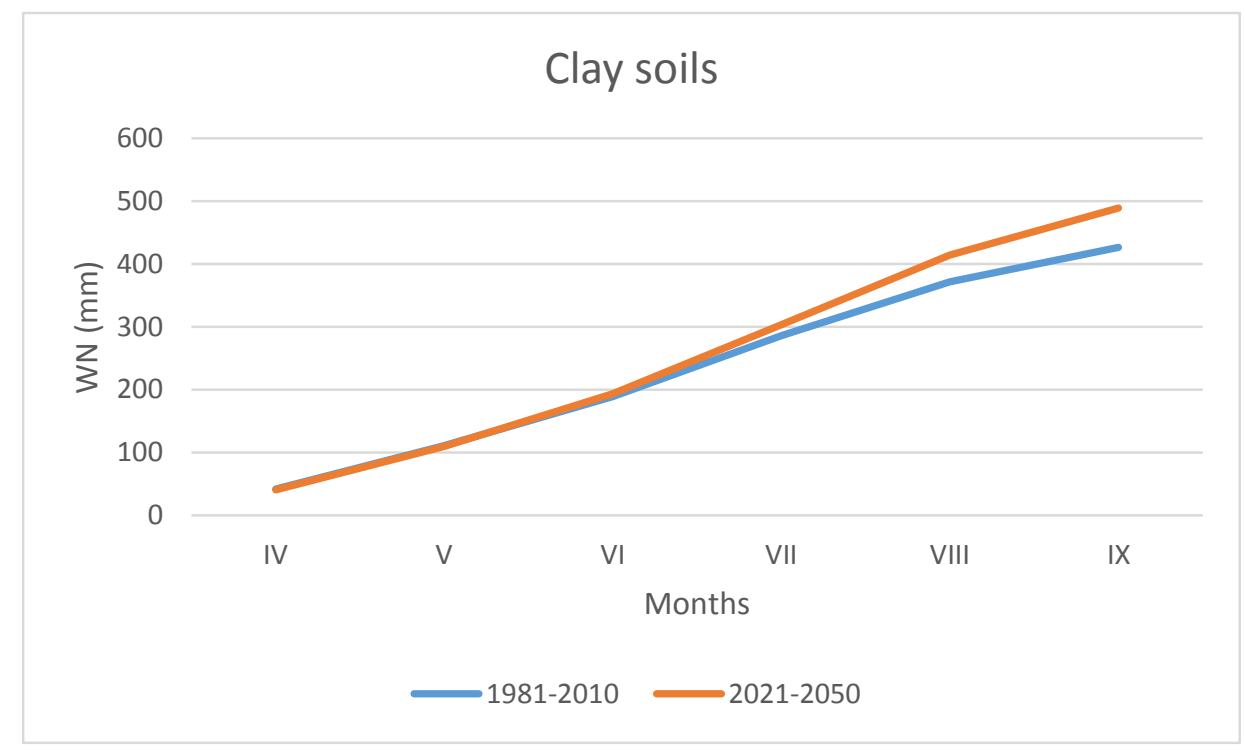

Figure 3. Water needs (WN) of forest nurseries located on the clay soils in the years 1981-2010 and 2021-2050 


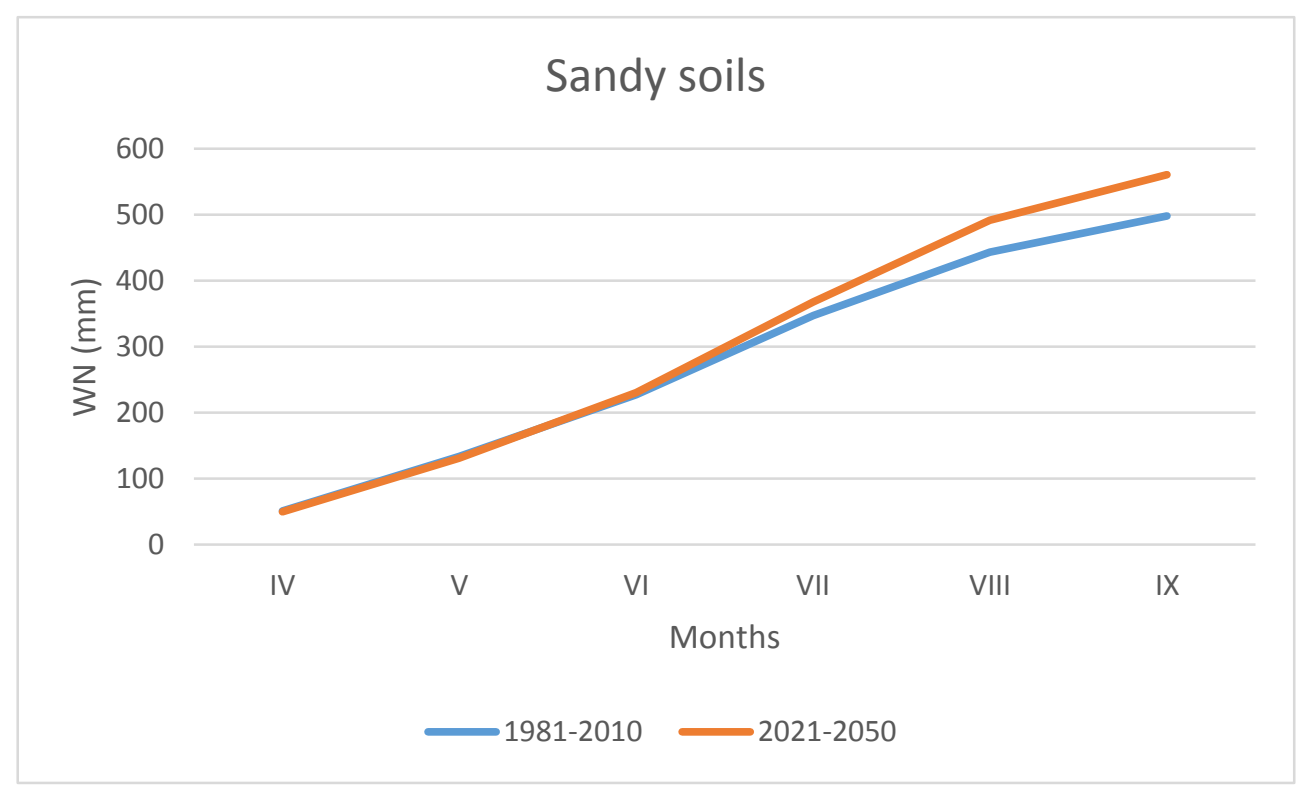

Figure 4. Water needs of forest nurseries located on the sandy soils in the years 1981-2010 and 2021-2050

In the case of both analyzed thirty-year periods, in July, the highest monthly water requirements were noted (Figures 1 and 2). In the years 1981-2010, the water needs were 96 and $120 \mathrm{~mm}$ on the clay and sandy soil, respectively, while in the forecasted period 2021-2050 the water requirements increased to 110 and $137 \mathrm{~mm}$ on the clay and sandy soil, respectively.

The water needs of forest nurseries in the particular months of the growing period are considerably higher in the predicted period 2021-2050 than during the reference years (Figures 3 and 4). In both compared thirty-year periods, the water requirements of forest nurseries located on the sandy soil are higher than in the case of clay soil (Figures 3 and 4).

Comparing to the reference period (1981-2010), the water needs of forest nurseries between April and September during the years 2021-2050 increased from 427 to $489 \mathrm{~mm}$ on clay soil and from 498 to $560 \mathrm{~mm}$ on sandy soil (Figure 5).

The increase of the total water requirements of forest nurseries during the growing months (April-September) in the years 2021-2050 is the result of monthly upward trends of water needs. However, significant upward trends in the water requirements of forest nurseries were calculated only in April and August (Table 2). The raise of water needs in April and August is caused by the expected air temperature increase in these months (Bąk and Labędzki, 2014). The authors suggested, that the average monthly air temperature in April and August in the years 2011-2050, according to the expected climate change in Poland (SRES: A1B), will significantly increase by $0.7^{\circ} \mathrm{C}$ decade $^{-1}$.

According to the linear regression analysis (calculated for the significant correlation coefficients), in April, the water needs of forest nurseries located on clay and sandy soil will increase by 3.3 and $3.8 \mathrm{~mm}$ decade $^{-1}$, respectively, (Figures 6 and 7), while in August, the water requirements will raise 5.4 and $6.0 \mathrm{~mm} \mathrm{decade}{ }^{-1}$, respectively (Figures 8 and 9).

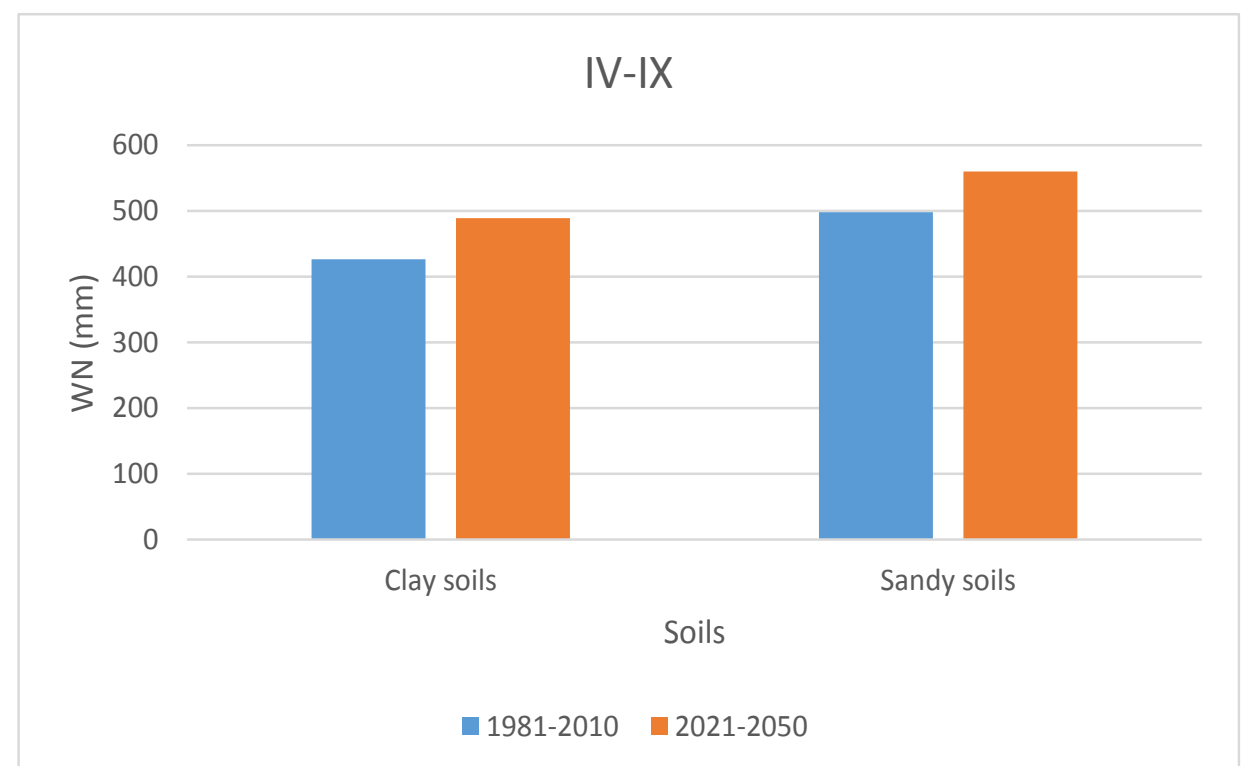

Figure 5. Total water needs (WN) of forest nurseries during the growing period in the years 1981-2010 and 2021-2050 
Table 2. Trends of water needs of the forest nurseries in the years 2021-2050

\begin{tabular}{|c|c|c|c|c|}
\hline \multirow[t]{2}{*}{ Specification } & \multicolumn{2}{|c|}{ Period from 1981 to 2010} & \multicolumn{2}{|c|}{ Period from 2021 to 2050} \\
\hline & clay soils & sandy soils & clay soils & sandy soils \\
\hline April & ns & ns & $0.315^{*}$ & $0.311 *$ \\
\hline May & ns & ns & ns & $\mathrm{ns}$ \\
\hline June & ns & ns & ns & ns \\
\hline July & ns & ns & ns & ns \\
\hline August & ns & ns & $0.325^{*}$ & $0.330 *$ \\
\hline September & ns & ns & ns & ns \\
\hline April-September & ns & $\mathrm{ns}$ & ns & $\mathrm{ns}$ \\
\hline
\end{tabular}

ns - not significant; *significant at the level $\alpha=0.1(\mathrm{p}=90 \%)$

The forecasted climate change, influenced the increase in the water needs of plants, including the seedlings produced in the forest nurseries, cause the adaptive actions, such as irrigation treatments. Nowadays, the watering is considered as one of the most important melioration treatments in the forest nurseries (Rzekanowski and Pierzgalski, 2006). However, along with the progressive unfavorable climate changes, the importance of the irrigation will increase (Kuchar and Iwański, 2011, 2013; Kuchar et al., 2015, 2017; Łabędzki, 2009; Żarski et al., 2013). The positive effects of the microirrigation and other melioration treatments (revitalization) on the development of plants produced in the forest nurseries in the region of Bydgoszcz were already observed in the case of species, such as Scots pine (Klimek et al., 2008), white birch (Klimek et al., 2009), European larch (Klimek et al., 2011) and littleleaf linden (Klimek et al., 2013).

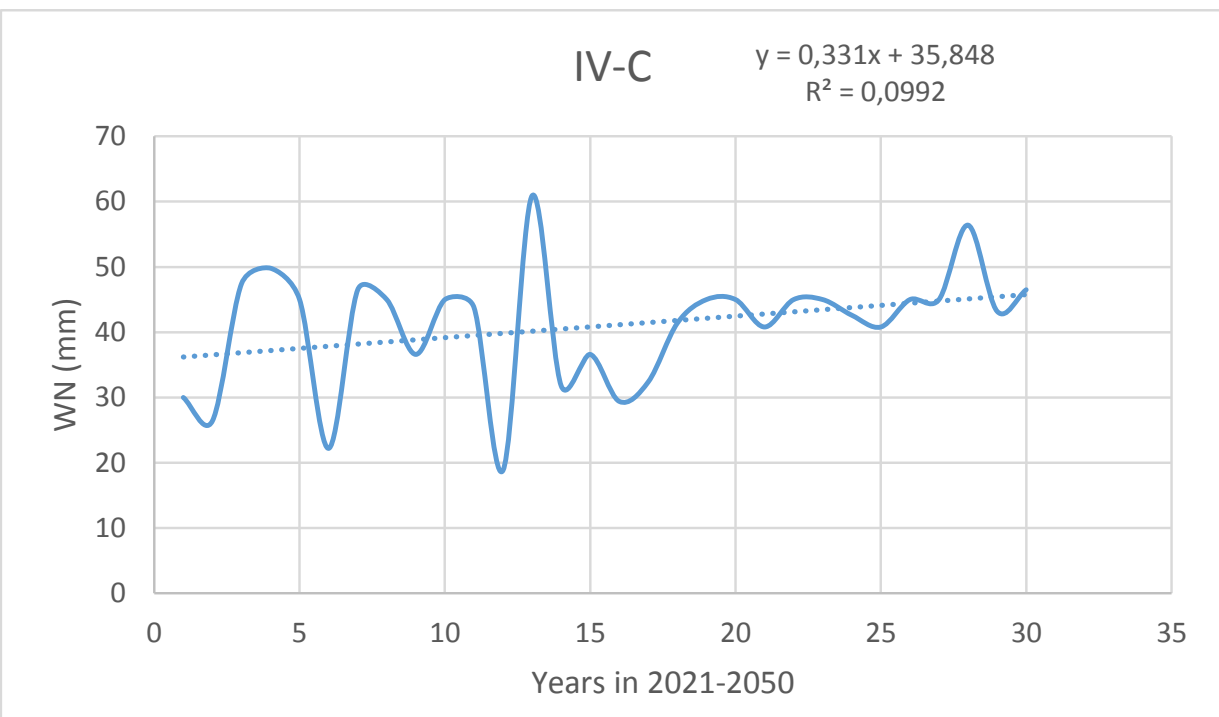

Figure 6. Temporal variability of the water needs (WN) of forest nursery located on the clay soils (C) in April (IV) in the years 2021-2050

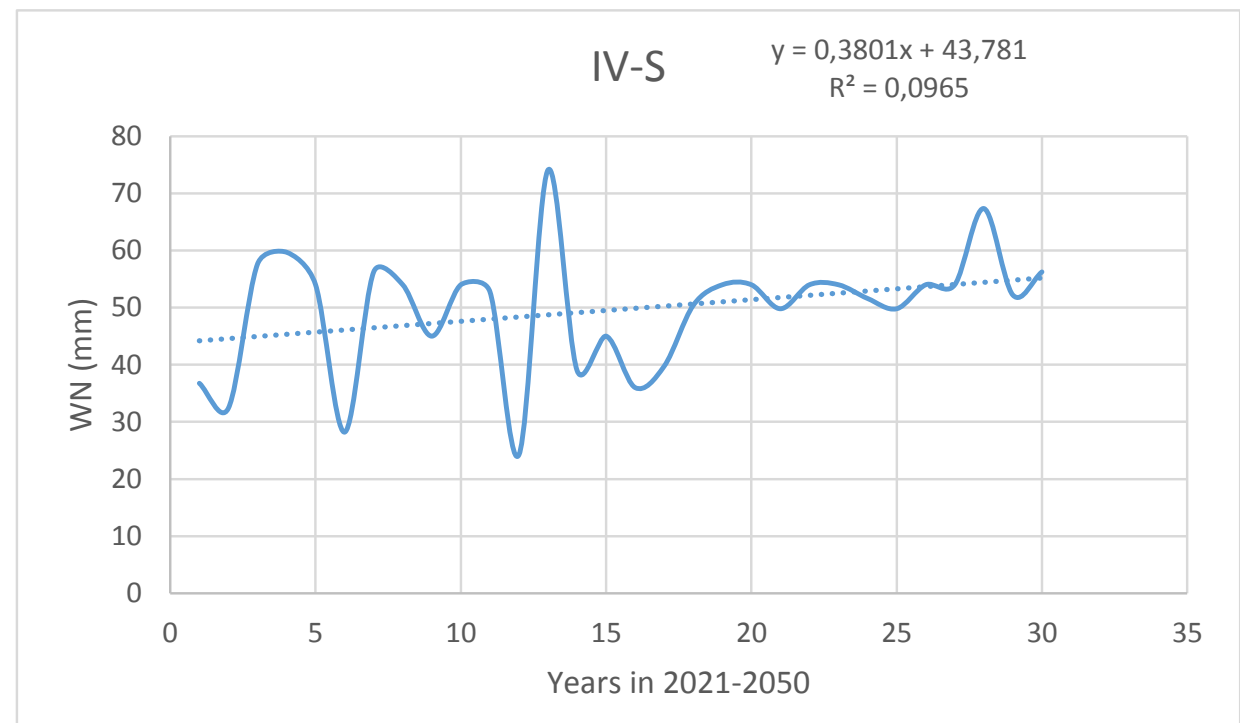

Figure 7. Temporal variability of the water needs (WN) of forest nursery located on the sandy soils (S) in April (IV) in the years 2021-2050 


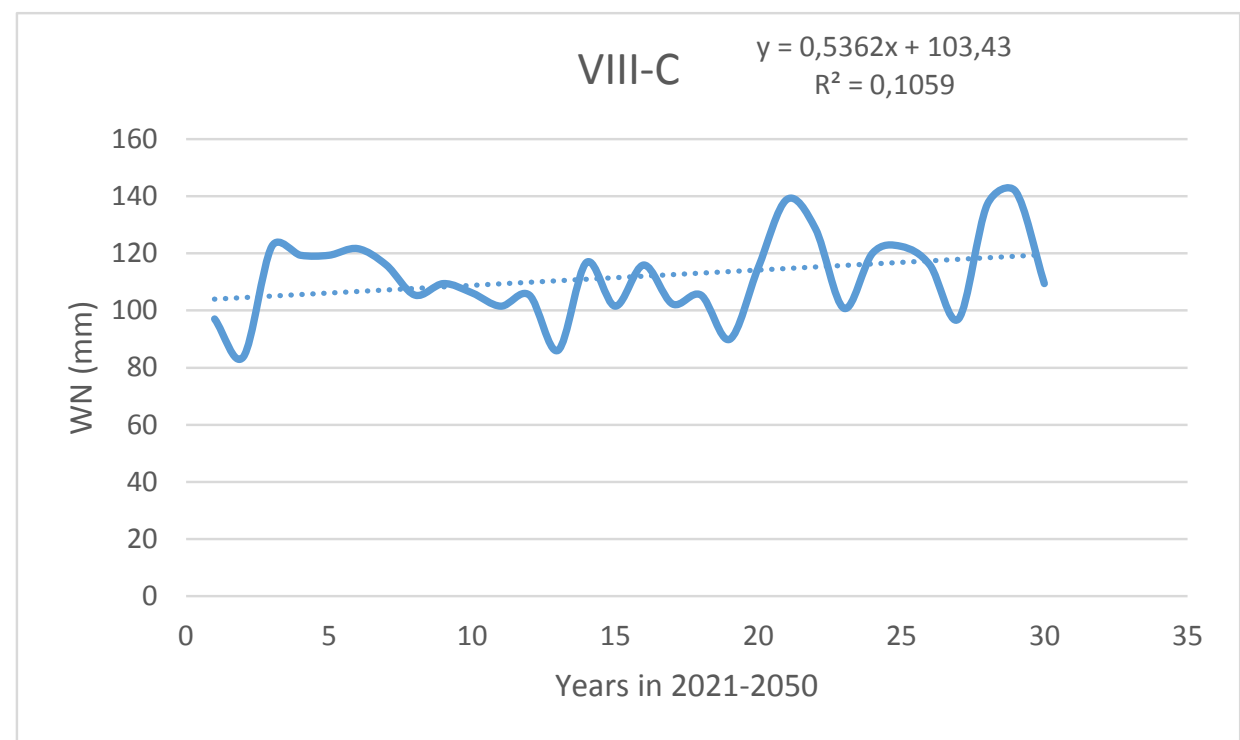

Figure 8. Temporal variability of the water needs (WN) of forest nursery located on the clay soils (C) in August (VIII) in the years 2021-2050

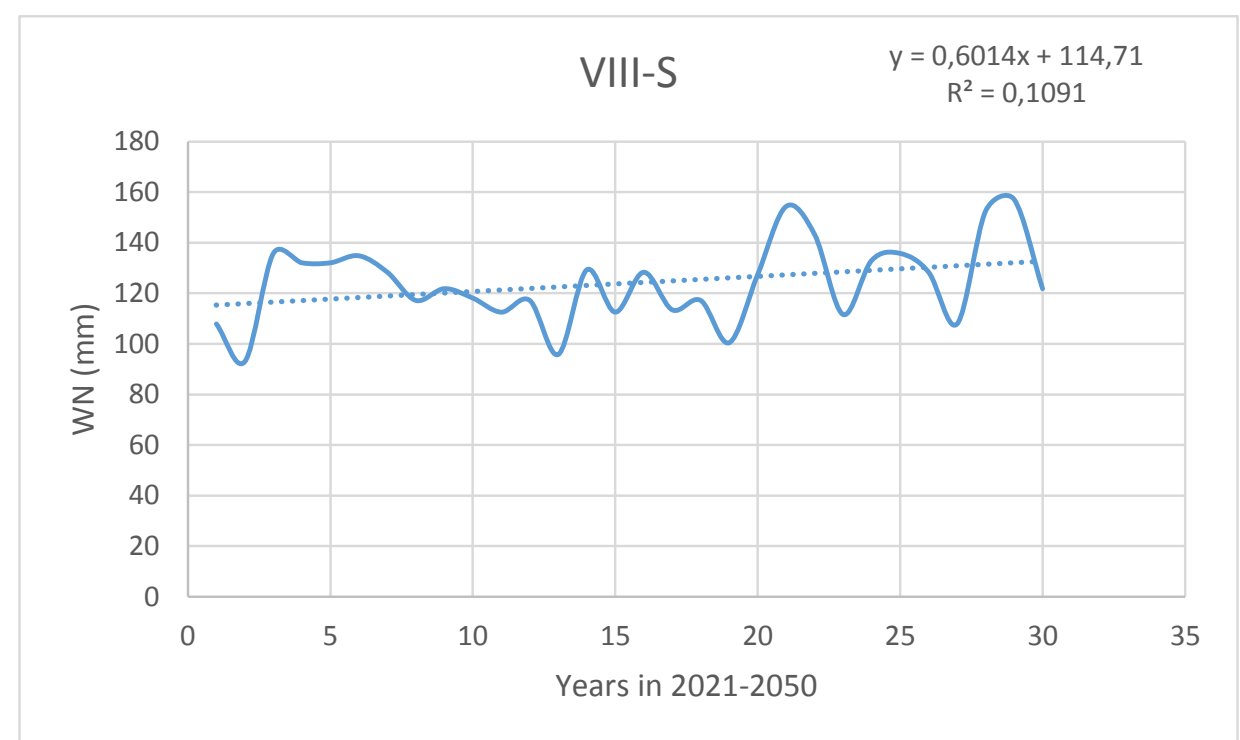

Figure 9. Temporal variability of the water needs (WN) of forest nursery located on the sandy soils (S) in August (VIII) $\mathrm{i}$ $\mathrm{n}$ the years 2021-2050

\section{CONCLUSIONS}

1. In the period 2021-2050 in the Bydgoszcz region, the increase of water needs of the forest nurseries in the range of $12-15 \%$ is expected. Comparing to the reference years (1981-2010), the water needs of nurseries in 2021-2050 will rise in the growing period (April-September) from 427 to $489 \mathrm{~mm}$ on clay and from 498 to $560 \mathrm{~mm}$ on sandy soil.

2. The greatest water needs, 110 and $137 \mathrm{~mm}$ on clay and sandy soil, respectively, will occur in July.

3. Correlation and regression analysis showed the significant rise of water needs of forest nurseries in 2021-2050, in

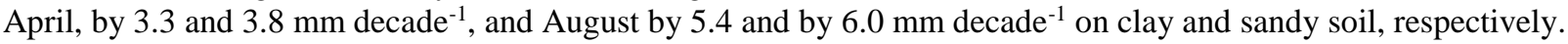

\section{REFERENCES}

1. Bąk, B., Łabędzki, L. 2014. Thermal conditions in Bydgoszcz region in growing seasons 2011-2050 in view of expected climate change. Journal of Water and Land Development, Vol. 23 pp. 21-29.

2. Grybauskiene, V., (Gitana Vyciene), Rolbiecki, R., Rolbiecki, S. 2018. Quality parameters evaluation of spruce (Picea abies) seedlings grown at open-nursery condition. Infrastructure and Ecology of Rural Areas (in press).

3. Klimek, A., Rolbiecki, S., Rolbiecki, R., Hilszczańska, D., Malczyk, P. 2008. Impact of chosen bare root nursery practices in Scots pine seedling quality and soil mites (Acari). Polish Journal of Environmental Studies, Vol. 17, Iss. 2, pp. $247-255$.

4. Klimek, A., Rolbiecki, S., Rolbiecki, R., Malczyk, P. 2009. Impact of chosen bare root nursery practices on white birch seedling quality and soil mites (Acari). Polish Journal of Environmental Studies, Vol. 18. Iss. 6, pp. 1013-1020.

5. Klimek, A., Rolbiecki, S., Rolbiecki, R., Hilszczańska, D., Malczyk, P. 2011. Effects of organic fertilization and mulching under micro-sprinkler irrigation on growth and mycorrhizal colonization of European larch seedlings, and occurrence of soil mites. Polish Journal of Environmental Studies, Vol. 5, Iss. 20, pp. 1211-1219. 
6. Klimek, A., Rolbiecki, S., Rolbiecki, R., Długosz, J., Musiał, M. 2013. The use of compost from sewage sludge and forest ectohumus for enrichment of soils in the nursery cultivation of littleleaf linden (Tilia cordata Mill.). Annual Set The Environment Protection, Vol. 15, pp. 2811-2828.

7. Kuchar, L., Iwański, S. 2011. Rainfall simulation for the prediction of crop irrigation in future climate. Infrastructure and Ecology of Rural Areas, Vol. 5, pp. 7-18.

8. Kuchar, L., Iwański, S. 2013. Rainfall evaluation for crop production until 2050-2060 and selected climate change scenarios for North Central Poland. Infrastructure and Ecology of Rural Areas, Vol. 2, No. I, pp. 187-200.

9. Kuchar, L., Iwański, S., Diakowska, E., Gąsiorek, E. 2015. Simulation of hydrothermal conditions for crop production purpose until 2050-2060 and selected climate change scenarios for North Central Poland. Infrastructure and Ecology of Rural Areas, No. II(1), pp. 319-334.

10. Kuchar, L., Iwański, S., Diakowska, E., Gąsiorek, E. 2017. Assessment of meteorological drought in 2015 for North Central part of Poland using hydrothermal coefficient (HTC) in the context of climate change. Infrastructure and Ecology of Rural Areas, No. I(2), pp. 257-273.

11. Łabędzki, L. 2009. Foreseen climate changes and irrigation development in Poland. Infrastructure and Ecology of Rural Areas, Vol. 3, pp. 7-18.

12. Orlińska-Woźniak, P., Wilk, P., Gębala, J. 2013. Water availability in reference to water needs in Poland. Meteorology Hydrology and Water Management, Vol. 1, pp. 45-50.https://doi.org/10.26491/mhwm/20546

13. Pierzgalski, E. 2009. Water in forest ecosystems. In: Water in non-urbanized areas. Papers of the Institute for Problems of Contemporary Civilization, Warszawa, pp. 41-55.

14. Pierzgalski, E., Tyszka, E., Boczoń, A., Wiśniewski, S., Jeznach, J., Żakowicz, S. 2002. Directives for irrigation of forest nurseries on bare areas. DGLP, Warszawa, pp. 1-63.

15. Rolbiecki, S., Musiał, M., Fórmaniak, A., Ryterska, H. 2010. Tentative estimation of irrigation needs of forest nurseries in 20002009 in vicinities of Bydgoszcz, Chojnice and Torun. Infrastructure and Ecology of Rural Areas, Vol. 14, pp. 23-30.

16. Rzekanowski, C., Pierzgalski, E. 2006. Irrigation of forest nurseries. In: Plant irrigation, (eds S. Karczmarczyk and L. Nowak). PWRiL. Poznań, pp.194-197.

17. Schmidt, G. A., Ruedy, R., Hansen, J. E., Aleinov, I., Bell, N., Bauer, M., Bauer, S., Cairns, B., Canuto, V., Cheng, Y., Del Genio, A., Faluvegi, G., Friend, A. D., Hall, T. M., Hu, Y., Kelley, M., Kiang, N. Y., Koch, D., Lacis, A. A., Lerner, J., Lo, K. K., Miller, R. L., Nazarenko, L., Oinas, V., Perlwitz, Ja., Perlwitz, Ju., Rind, D., Romanou, A., Russell, G. L., Sato, M., Shindell, D. T., Stone, P. H., Sun, S., Tausnev, N., Thresher, D., Yao, M. S. 2006. Present day atmospheric simulations using GISS Model E: Comparison to in-situ, satellite and reanalysis data. Journal of Climate, Vol. 19, pp. $153-192$. https://doi.org/10.1175/JCLI3612.1

18. Żarski, J., Dudek, S., Kuśmierek-Tomaszewska, R., Rolbiecki, R., Rolbiecki, S. 2013. Forecasting effects of plants irrigation based on selected meteorological and agricultural drought indices. Annual Set The Environment Protection, Vol. 15, pp. 2185-2203. 